\title{
UDC 544.723.22 \\ ADSORPTION OF CADMIUM IONS ISOTHERM FROM WATER INTO POLYMER NANOCOMPOSITE
}

\author{
J.R. Imanova, A.A. Azizov, A.M. Nabiev, F.G. Khalilova, R.M. Alosmanov \\ Baku State University \\ Z. Khalilov str., 23, BakuAZ 1148, Azerbaijan Republic : e-mail: r ralosmanov@rambler.ru
}

\begin{abstract}
Polymer nanocomposite with zerovalent iron particles was used to remove $C d^{2+}$ from water. The adsorption of $\mathrm{Cd}^{2+}$ was examined as a function of initial metal ion concentration. Also, the equilibrium data were analyzed on the basis of various adsorption isotherm models, specifically Langmuir, Freundlich, Temkin, and Dubinin-Radushkevich. The results showed that the adsorption process was in agreement with the Langmuir isotherm model.

Keywords: polymer nanocomposite, adsorption, Langmuir isotherm, cadmium ions
\end{abstract}

\section{INTRODUCTION}

Cadmium is a toxic heavy metal of particular environmental and occupational importance [1]. It is discharged into the environment through the combustion of fossil fuels, metal production, application of phosphate fertilizers, electroplating, and the manufacturing of batteries, pigments, and screens [2-4]. This heavy metal leads to serious contamination of both soil and water. Cadmium has been classified as a human carcinogen and teratogen affecting lungs, kidneys, liver and reproductive organs [1,5]. The World Health Organization (WHO) has set a criterion of maximum concentration of $0.003 \mathrm{mg} / \mathrm{L}$ for $\mathrm{Cd}$ in drinking water [6]. Given the pervasive cadmium contamination and the low drinking water basis, there is an upsurge of interest in the development of techniques to remove cadmium from contaminated water. Thus, scholars are focusing on the removal and recovery of cadmium, including various methods such as chemical precipitation [7], reduction-oxidation [8], ion-exchange [9], forward osmosis [10], biological process [11] which have been introduced for removal of cadmium from the aqueous solution. Among the different methods described above, adsorption process is attractive in consideration of its efficiency, economy and ease of operation, especially as lots of studies on the theme have been carried out [12-14].

The objective of the research is to inquire into the adsorption isotherm models and the cadmium removal by polymer nanocomposite (PNC).

\section{MATERIALS AND METHODS}

\section{Preparation of PNC}

For preparation of PNC, commercial, sulfonated styrene-divinylbenzene and crosslinked copolymer has been used as polymer. Note that the synthesis of PNC is based on borohydride reduction of $\mathrm{Fe}^{2+}$. Polymer $(1.0 \mathrm{~g})$ has been added to the stirred ethanol solution of $\mathrm{FeCl}_{2} \cdot 4 \mathrm{H}_{2} \mathrm{O}(0.4 \mathrm{M}, 300 \mathrm{ml})$. Also, $1 \mathrm{M}$ $\mathrm{NaBH}_{4}$ solution has then been added dropwise to the Fe-polymer mixture with continuous stirring of the resulting solution. After the addition of $\mathrm{NaBH}_{4}$ solution, the mixture has been stirred for additional $20 \mathrm{~min}$,
PNC collected and washed thrice with isopropanol to prevent oxidation. Deionized deoxygenated water (sparged with nitrogen) used to prepare aqueous solutions.

\section{Adsorption studies}

Batch adsorption experiments have been carried out to enable an accurately weighted amount of PNC reach equilibrium with $\mathrm{Cd}^{2+}$ aqueous solutions of various initial concentrations between 20 and $400 \mathrm{mg} / \mathrm{L}$ and temperatures ranging around $25{ }^{\circ} \mathrm{C}$. Besides, the weighed samples of sorbent $(0.1 \mathrm{~g})$ have been placed into bottles and filled up with 
solutions $(0.3 \mathrm{~L})$. The bottles underwent stirring by a temperature-controlled shaker (IKA, Germany). In 24 hours the solution has been filtrated and the concentration of $\mathrm{Cd}^{2+}$ in

$$
\begin{aligned}
& q=\left(C_{0}-C_{\mathrm{eq}}\right) \cdot \frac{V}{m} \\
& R=\frac{\left(C_{0}-C_{\mathrm{eq}}\right)}{C_{0}} \cdot 100 \%
\end{aligned}
$$

where $C_{0}, C_{\text {eq }}-$ initial and equilibrium concentration of $\mathrm{Cd}^{2+}$ in solution respectively, $\mathrm{mg} / \mathrm{L}, V$ - solution volume and $m$ - sorbent dose $(\mathrm{g})$.

All experiments have been performed in duplicate.

\section{RESULTS AND DISCUSSION}

Effect of initial $\mathrm{Cd}^{2+}$ concentration on adsorption process.

Table 1 shows that the equilibrium adsorption capacity of sorbent rises together with the increase of initial concentration of $\mathrm{Cd}^{2+}$ up to $420 \mathrm{mg} / \mathrm{L}$. This is explained as being due to the fact that the initial concentration of solute provides the major driving force to overcome the mass transfer resistance. Rise in loading capacity of PNC at high initial concentrations of $\mathrm{Cd}^{2+}$ may also be due to the appreciable interaction between metal ions and sorbent surface.

Table 1. Equilibrium uptake capacities and adsorption degree at different initial concentrations for $\mathrm{Cd}^{2+}$

\begin{tabular}{|c|c|c|}
\hline $\mathrm{C}_{0}, \mathrm{mg} / \mathrm{L}$ & $\mathrm{q}_{\mathrm{eq}}, \mathrm{mg} / \mathrm{g}$ & $\mathrm{R}, \%$ \\
\hline 20 & 5.9 & 89.00 \\
\hline 40 & 11.5 & 86.00 \\
\hline 60 & 16.4 & 82.17 \\
\hline 80 & 21.5 & 80.75 \\
\hline 100 & 26.2 & 78.60 \\
\hline 125 & 31.4 & 75.36 \\
\hline 150 & 37.1 & 74.20 \\
\hline 175 & 43.0 & 73.66 \\
\hline 200 & 47.8 & 71.70 \\
\hline 225 & 52.8 & 70.36 \\
\hline 250 & 56.5 & 67.76 \\
\hline 275 & 60.3 & 65.75 \\
\hline 300 & 62.4 & 62.43 \\
\hline 325 & 64.2 & 59.26 \\
\hline 350 & 67.0 & 57.40 \\
\hline 380 & 67.7 & 53.47 \\
\hline 400 & 69.2 & 51.90 \\
\hline 420 & 69.8 & 49.88 \\
\hline
\end{tabular}

The maximum value of adsorption degree was identified as being due to $89.00 \%$ at $20.0 \mathrm{mg} / \mathrm{L}$. The results demonstrate a tendency toward decrease in adsorption degree as the initial $\mathrm{Cd}^{2+}$ concentration rose. At low initial concentrations all sorbate from the adsorption medium tend to interact with binding sites of the sorbent leading to higher degrees of adsorption. In contrast, at high initial concentrations of $\mathrm{Cd}^{2+}$, low adsorption degrees became apparent due to the saturation of adsorption sites. 


\section{Adsorption isotherms}

Equilibrium data may be analyzed using well-known adsorption isotherms which provide for the basis of adsorption systems. The most widely used isotherm equation for modeling the adsorption data is the Langmuir equation which is valid for monolayer sorption on the surface with a finite number of identical sites defined by Equation (3).

$$
q_{\mathrm{eq}}=\frac{q_{\mathrm{max}} K_{\mathrm{L}} C_{\mathrm{eq}}}{1+K_{\mathrm{L}} C_{\mathrm{eq}}}
$$

where $K_{\mathrm{L}}$ is the adsorption equilibrium constant representing the affinity of binding sites $(\mathrm{L} / \mathrm{g})$ and $q_{\max }$ is the maximum amount of AR per PNC unit weight to form a complete monolayer on the surface $(\mathrm{mg} / \mathrm{g})$. It presents a practical limiting adsorption capacity in case where the surface is fully covered with metal ions. $q_{\max }$ and $K$ can be determined from the linear plot of $C_{\mathrm{eq}} / q_{\mathrm{eq}}$ versus $C_{\mathrm{eq}}$ [15].

The Freundlich model is an empirical equation based on sorption on the heterogeneous surface. It is given as:

$$
q_{\mathrm{eq}}=K_{\mathrm{F}} C_{\mathrm{eq}}^{1 / \mathrm{n}}
$$

where $K_{\mathrm{F}}$ and $n$ are the Freundlich constants that indicate relative capacity and adsorption intensity, respectively. The Freundlich equation can be linearized by taking logarithms and constants [16].

Temkin isotherm is another adsorption model considering adsorbent-adsorbate interactions. The model assumes that these interactions cause a decrease in the heat of adsorption of molecules in the layer and the binding energies show a uniform distribution in the adsorption process [17]. This isotherm can be expressed by the following formula:

$$
q_{\mathrm{e}}=B \ln A+B \ln C_{\mathrm{eq}}
$$

In Equation (5) constant $A$ denotes Temkin constant used to examine adsorbateadsorbate interactions and $B$ is the constant related to adsorption heat. $\mathrm{A}$ and $\mathrm{B}$ can be determined from plot of $q_{\mathrm{e}} \mathrm{vs} . \ln C_{\mathrm{e}}$.

The Dubinin-Radushkevich isotherm model is a semi-empirical equation where adsorption follows a pore filling mechanism. It assumes that the adsorption has a multilayer character, involves van der Waals forces and is applicable for physical adsorption processes. The Dubinin-Radushkevich [18] equation has the following form

$$
q_{\mathrm{e}}=q_{\mathrm{m}} e^{-\beta \varepsilon^{2}}
$$

where $q_{\mathrm{m}}$ is the theoretical isotherm saturation capacity $(\mathrm{mg} / \mathrm{g}), \beta$ is a constant related to the sorption energy, and $\varepsilon$ is the Polanyi potential which is related to the equilibrium concentration as follows

$$
\varepsilon=R T \ln \left(1+\frac{1}{C_{\mathrm{eq}}}\right)
$$

where $R$ is the gas constant $\left(8.314 \mathrm{~J} \mathrm{~mol}^{-}\right.$ $\left.{ }^{1} \mathrm{~K}^{-1}\right)$ and $T$ is the absolute temperature.

The constant $\beta$ gives the mean free energy, $E$, of sorption per molecule of the sorbate when it is transferred to the surface of the solid from infinity in the solution and can be computed using the relationship

$$
E=\frac{1}{\sqrt{2 \beta}}
$$

The $\beta$, and $q_{\mathrm{m}}$ parameters can be determined from plot of $\ln C_{\mathrm{eq}}$ versus $\varepsilon^{2}$.

All obtained isotherm constants and correlation coefficients are listed in Table 2.

Table 2. Langmuir, Freundlich, Temkin, and Dubinin-Radushkevich isotherm model parameters and correlation coefficients for adsorption of cadmium on PNC

\begin{tabular}{|l|c|c|c|}
\hline \multirow{3}{*}{ Langmuir } & \multicolumn{3}{|c|}{ Parameters } \\
\cline { 2 - 4 } & $\mathrm{K}_{\mathrm{L}}, \mathrm{L} / \mathrm{g}$ & $\mathrm{q}_{\max }, \mathrm{mg} / \mathrm{g}$ & $\mathrm{r}^{2}$ \\
\cline { 2 - 4 } & 0.022 & 90.91 & 0.9940 \\
\hline \multirow{3}{*}{ Freundlich } & \multicolumn{3}{|c|}{ Parameters } \\
\cline { 2 - 4 } & $\mathrm{K}_{\mathrm{F}}$ & $\mathrm{n}$ & $\mathrm{r}^{2}$ \\
\cline { 2 - 4 } & 4.677 & \multicolumn{3}{|c|}{ Parameters } \\
\hline Temkin & \multicolumn{3}{|c|}{0.9740} \\
\hline
\end{tabular}




\begin{tabular}{|l|c|c|c|c|}
\hline \multirow{3}{*}{ Dubinin-Radushkevich } & $\mathrm{A}$ & $\mathrm{B}$ & \multicolumn{2}{|c|}{$\mathrm{r}^{2}$} \\
\cline { 2 - 5 } & 0.3878 & 16.47 & \multicolumn{2}{|c|}{0.9570} \\
\cline { 2 - 5 } & \multicolumn{4}{|c|}{ Parameters } \\
\cline { 2 - 5 } & $\mathrm{q}_{\mathrm{m},}$ & $\beta 10^{6}$, & $\mathrm{E}, \mathrm{kC} / \mathrm{mol}$ & $\mathrm{r}^{2}$ \\
\cline { 2 - 5 } & 44.36 & 2.0 & 0.5 & 0.5570 \\
\hline
\end{tabular}

As the four systems reviewed, Langmuir isotherm correlates $\left(r^{2}>0.9900\right)$ rather with the experimental data of adsorption equilibrium of $\mathrm{Cd}^{2+}$ on the PNC than Freundlich, Temkin and DubininRadushkevich isotherms. The adsorption data of metal ions in accordance with the Langmuir isotherm shows that the binding energy of the entire surface of PNC is uniform. By the way, the whole surface has an identical adsorption activity. In line with Langmuir isotherm, the adsorption data of $\mathrm{Cd}^{2+}$ also show that the adsorbed ions do not interact or compete with each other to form a monolayer. This phenomenon also indicates that chemisorption has the principal removal mechanism in the adsorption process. The maximum adsorption $\left(q_{\max }\right)$ values for $\mathrm{Cd}^{2+}$ are in good accordance with the experimentally obtained values.

As seen from Table 2, according to Freindlich model the $n$ value was found to make up above $>1.0$. The value of $E$ as set forth in Dubinin-Radushkevich model is less than $1 \mathrm{kC} / \mathrm{mol}$. From this it follows that the physical adsorption process prevails. However, in line with this model the value of correlation coefficient the regression parameter $r^{2}$ (0.5570) showed that this isotherm model did not provided a very good fit to the experimental data.

\section{REFERENCES}

1. Waalkes M.P. Cadmium carcinogenesis in review. J. Inorg. Biochem. 2000, vol. 79, pp. 241244.

2. Sharma Y.C. Thermodynamics of removal of cadmium by adsorption on an indigenous clay. Chem. Eng. J. 2008, vol. 145, pp.64-68.

3. Alloway B.J., Steinnes E. Anthropogenic additions of cadmium to soils, in: M.J. McLaughlin, B.R. Singh (Eds.). Cadmium in Soils and Plants, Kluwer Academic Publishers, Boston, 1999, pp. 97-124.

4. Perez-Marin A.B., Zapata V.M., Ortuno J.F. et al. Removal of cadmium from aqueous solutions by adsorption onto orange waste. J Hazard Mater. 2007, vol.139, pp.122-131.

5. Mahalik M.P., Hitner H.W., Prozialeck W.C. Teratogenic effects and distribution of cadmium $\left(\mathrm{Cd}^{2+}\right)$ administered via osmotic mini pumps to gravid Cf-1 mice. Toxicol. Lett. 1995, vol. 76, pp. 195-202.

6. WHO, Guidelines for Drinking Water Quality: Recommendations, vol. 1, 3rd ed., World Health Organisation, Geneva, 2008.

7. Bhatluri K.K., Manna M.S., Ghoshal A.K., Saha P. Supported liquid membrane based removal of lead(II) and cadmium(II) from mixed feed: conversion to solid waste by precipitation // J Hazard Mater. 2015, Dec 15;299, pp.504-512.

8. Hizal J., Apak R. Modeling of cadmium(II) adsorption on kaolinite-based clays in the absence and presence of humic acid. Appl Clay Sci. 2006, vol. 32, pp. 232-244.

9. Wei W., Bediako J.K., Kim S., Yun Y.S. Removal of $\mathrm{Cd}(\mathrm{II})$ by poly(styrenesulfonic acid)impregnated alginate capsule. J Taiwan Inst Chem E. 2016, vol. 61, pp.188-95.

10.Cui Y., Ge Q.C., Liu X.Y., Chung T.S. Novel forward osmosis process to effectively remove heavy metal ions. J Membrane Sci. 2014, vol. 467, pp.188-194.

11.Boschi C., Maldonado H., Ly M., Guibal E. Cd(II) biosorption using Lessonia kelps. J Colloid Interf Sci. 2011, vol. 357, pp. 487-496.

12.Oliva J., Pablo J.D., Cortina J.L. et al. Removal of cadmium, copper, nickel, cobalt and mercury from water by apatite II TM: Column experiments. J Hazard Mater. 2011, vol. 194, pp. 312-323.

13.Crini G. Recent developments in polysaccharide-based materials used as adsorbents in wastewater treatment. Prog Polym Sci. 2005, vol. 30, pp.38-70.

14.Corami A., Mignardi S., Ferrini V. Cadmium removal from single- and multi-metal solutions by sorption on hydroxyapatite. J Colloid Interf Sci. 2008, vol. 317, pp. 402-408.

15.Langmuir I. The Constitution And Fundamental Properties Of Solids And Liquids. Part I. Solids. JACS. 1916, vol. 38, pp. 2221-2295.

16.Freundlich H.M. Over the Adsorption in Solution. Z. Phys. Chem. 1906, vol. 57, pp. 385- 
471.

17. Temkin M.I., Pyzhev V. Kinetic of Ammonia Synthesis on Promoted Iron Catalyst. Acta. Phys. Chim. Sin. 1940, vol. 12, pp. 327-356.

18. Dubinin M.M., Radushkevich I.A. Equation of the Characteristic Curve of Activated Charcoal. Proceedings of the Academy of Sciences, Physical Chemistry Section. 1947, vol. 55, pp. 331-337.

\title{
ИЗОТЕРМА СОРБЦИИ ИОНОВ КАДМИЯ ИЗ ВОДЫ НА ПОЛИМЕРНОМ НАНОКОМПОЗИТЕ
}

\author{
Дже.Р. Иманова, А.А. Азизов, А.М. Набиев, Ф.Г. Халилова, Р.М. Алосманов \\ Бакинский государственный университет \\ AZ 1148 Баку, ул. 3.Халилова, 23; e-mail: $\underline{r \text { alosmanov@rambler.ru }}$
}

Для удаления ионов $\mathrm{Cd}^{2+}$ из воды использовали полимерный нанокомпозит с нульвалентными частицами железа. Адсорбцию $\mathrm{Cd}^{2+}$ исследовали в зависимости от начальной концентрации иона металла. Данные о равновесии анализировали на основе различных моделей изотерм адсорбиии, а именно, Ленгмюра, Фрейндлиха, Темкина и Дубинина-Радушкевича. Результаты показали, что прочесс адсорбиии согласуется с моделью Ленгмюра.

Ключевые слова: полимерный нанокомпозит, адсорбиия, изотерма Ленгмюра, ионы $\mathrm{Cd}^{2+}$

\section{KADMIUM IONLARININ SULU MOHLULLARDAN POLIMER NANOKOMPOZITLO SORBSIYA IZOTERMI}

\author{
C.R. Imanova, A.Ө. Әzizov, A.M. Nəbiyev, F.Q. Xəlilova, R.M. Alosmanov \\ Bakı Dövlat Universiteti \\ AZ 1148 Bakı, Z.Xəlilov kü̧̈., 23; e-mail:r alosmanov@,rambler.ru
}

Kadmium ionlarının sudan kənarlaşdırılması üçün tarkibində sıfır valentli damir hissaciklari olan polimer nanokompozit istifado olunmuşdur. Kadmium ionlarının sorbsiyası metal ionlarının ilkin qatıllğından asılı olaraq tədqiq edilmişdir. Sorbsiya izotermi Lenqmür, Freyndlix, Temkin və Dubinin-Raduşkeviç modellarila işlanmişdir. Müayyan olunmuşdur ki, sorbsiya prosesi Lenqmür izoterm modeli ila yaxşı tasvir olunur.

Açar sözlor: polimer nanokompozit, adsorbsiya, Lenqmür izotermi, kadmium ionları

Received 27.01.2018. 